\title{
Positive Predictive Value of Diabetes Risk Assessment as a Screening Test
}

\author{
Maryam Baradaran Binazir* and Hajar Islamifar \\ Social Determinants of Health Research Center, University of Medical Sciences, Iran
}

Submission: May 30, 2019; Published: June 26, 2019

*Corresponding author: Maryam Baradaran Binazir, Social Determinants of Health Research Center, Health Management and Safety Promotion Research Institute, Tabriz, University of Medical Sciences, Tabriz, Iran

\begin{abstract}
There is a long asymptomatic duration in which the type 2 diabetes can be diagnosed and a considerable percentage of persons with type 2 diabetes are undetected. So, it is important to evaluate diabetes screening tests. The aim of this study was evaluating risk assessment as a screening test. A cross-sectional study was done in four villages of Ajabshir, one of East Azerbaijan 's cities in Iran. The total population of the four villages, namely shiraz, Razyan, Nasna, and Pesyn was 4058. 2370 people were more than 30years old in these villages. Out of 1207 people, who had at least one risk factor, 67 persons were diabetics or prediabetics. The PPV of the risk factor assessment was 5.4\%, so the ability of the risk factor assessment to predict individuals with prediabetes and type 2 diabetes was significantly poor.
\end{abstract}

Keywords: Positive predictive value; Diabetes; Screening; Prediabetes; Type 2 diabetes; Glucose tolerance; Glycaemia; Chronic hyperglycaemia; Insulin secretion; Insulin; Blood glucose control

Abbreviations: PPV: Positive Predictive Value; IGT: Impaired Glucose Tolerance; IFG: Impaired Fasting Glycaemia

\section{Introduction}

Diabetes mellitus is a metabolic condition identified by chronic hyperglycaemia with malfunction of carbohydrate, fat and protein processes relate to imperfection in insulin secretion, insulin action, or both. In asymptomatic individuals, doing the test on one time is not adequate to confirm the diabetes [1]. This must be established by carrying out at least one further test on a later day. Impaired glucose tolerance (IGT) and impaired fasting glycaemia (IFG) are risk classifications for the future happening of diabetes and cardiovascular disease [2]. Many complications happen if diabetes persists untreated [3].

The diabetes epidemic is increasing in the developing world, with a rising percentage of diabetic people in younger age groups [4]. New studies report type 2 diabetes being detected in children and adolescents [5]. This is probably to rise additionally the burden of chronic diabetic consequences throughout the world.

The major logics for the present concerns in screening for type 2 diabetes are:

a) That there is a long asymptomatic duration in which the disease can be diagnosed.

b) A considerable percentage of persons with type 2 diabetes are undetected. c) A considerable percentage of newly diagnosed cases of type 2 diabetes previously have sign of the complications of diabetes.

d) The increasing rate of type 2 diabetes throughout the world.

e) The significance of the early effects and long-term consequences of type 2 diabetes.

f) Studies supporting the effectiveness of comprehensive blood glucose control [6] increased quality of life and any preserving or rearrangement of health care incomes are the potential advantages of early diagnosis of type 2 diabetes [7]

Many researchers are conducting experiments for screening the diabetes using various approaches like Decision Tree, Decision Table etc [8]. This research focused on 30 years and older rural population for evaluating risk assessment as a screening test. Positive Predictive Value were to find the prediction of type 2 diabetes and prediabetes in a patient.

A cross-sectional study was done in four villages of Ajabshir, one of East Azerbaijan 's cities in Iran. Four villages out of the forty villages in the Ajabshir were chosen as regarded concerns about arranging the population in the villages and the location of existing foundation. In these four villages, Behvarzes were 
carried out diabetes mellitus risk assessment as a screening program in health houses. Behvarzes were selected from their own village. They worked in "Health House," which is the most minor health center in the rural areas of Iran. These four centers carried out screening activities between March 2018 to March 2019. Screening for diabetes was recommended for all individuals older than 30 years of age living in selected villages. participants were interviewed and examined to assess the presence of risk factors of diabetes mellitus. Risk factors included family history of diabetes mellitus, overweight or obesity (BMI>25), previously identified impaired fasting glucose or impaired glucose tolerance. Among participants those even with one risk factor, the screening test result was considered positive and they directly were referred to a primary care doctors for identification of individuals with undiagnosed type 2 diabetes and pre-diabetes.

The total population of the four villages, namely shiraz, Razyan, Nasna, and Pesyn was 4058. 2370 people were more than 30 years old in these villages. Out of 1207 people, who had at least one risk factor, 67 persons were diabetics or prediabetics. The PPV of the risk factor assessment was $5.4 \%$, so the ability of the risk factor assessment to predict individuals with prediabetes and type 2 diabetes was significantly poor (94\% of individuals with risk factors were not prediabetic or diabetic).

In the similar study conducted at a health fair in Greensburg. In addition to risk assessment which done in our investigation, Fasting plasma glucose levels were obtained. PPV of this screening test was $20 \%$ which regarded poor for predicting prediabetes and type 2 diabetes [9].

in the Australian Aus Diab study, PPV of risk assessment alone for Undiagnosed type 2 diabetes was $7 \%$ which considered poor, as well as other studies [10].

This work is licensed under Creative Commons Attribution 4.0 Licens DOI: 10.19080/CRDOJ.2019.11.555808

\section{Conclusion}

The PPV of risk factor assessment for identifying prediabetics and diabetics is poor. The risk assessment did not work well to identify at risk individuals, reasonably needing early intervention and education.

\section{References}

1. (2009) Definition, Diagnosis and Classification of Diabetes Mellitus and its Complications. Report of a WHO Consultation. World Health Organization. Geneva, Switzerland.

2. Unwin N, Shaw J, Zimmet P, Alberti G (2012) International Diabetes Federation IGT/IFG Consensus Statement. Report of an Expert Consensus Workshop 1-4 August 2001, Stoke Poges, UK. Diabetic Medicine 19: 777-723.

3. Morrish NJ, Wang SL, Stevens LK, Fuller JH, Keen H (2001) Mortality and causes of death in the WHO multinational study of vascular disease in diabetes. Diabetologia 44(Suppl 2): S14-S21.

4. Wild S, Roglic G, Sicree R, Green A, King H (2003) Global burden of diabetes mellitus in the year 2000. Global Burden of Disease, WHO, Geneva, Switzerland.

5. Rosenbloom AL, Joe JR, Young RS, Winter WE (2009) Emerging epidemic of type 2 diabetes in youth. Diabetes Care 22(2): 345-354.

6. Ralston J, Reddy KS, Fuster V, Narula J (2016) Cardiovascular diseases on the global agenda: The United Nations high level meeting, sustainable development goals, and the way forward. Global heart 11(4): 375379.

7. (2008) Tight blood pressure control and risk of macrovascular complications in type 2 diabetes: UKPDS 38. UK Prospective Diabetes Study Group. BMJ 317(7168): 703-713.

8. Iyer A, Jeyalatha S, Sumbaly R (2015) Diagnosis of diabetes using classification mining techniques.

9. Behan KJ (2005) Screening for diabetes: Sensitivity and positive predictive value of risk factor total. Clin Lab Sci 18(4): 221-225.

10. Cameron A (2010) The metabolic syndrome: validity and utility of clinical definitions for cardiovascular disease and diabetes risk prediction. Maturitas 65(2): 117-121.

\begin{tabular}{l} 
Your next submission with Juniper Publishers \\
will reach you the below assets \\
- Quality Editorial service \\
- Swift Peer Review \\
- Reprints availability \\
- E-prints Service \\
- Manuscript Podcast for convenient understanding \\
- Global attainment for your research \\
- Manuscript accessibility in different formats \\
( Pdf, E-pub, Full Text, Audio) \\
- Unceasing customer service \\
Track the below URL for one-step submission \\
https://juniperpublishers.com/online-submission.php \\
\hline
\end{tabular}

